\title{
ADDITIONAL RECORDS OF ONYCHOPHORA FROM THE ISLAND OF HAITI
}

\author{
By Charles T. Brues \\ Biological Laboratories, Harvard University
}

When he visited Haiti several years ago Dr. P. J. Darlington, of the Museum of Comparative Zoology, obtained specimens of Onychophora from a number of localities in the Republic of Haiti. These proved to represent five distinguishable forms of the genus Peripatus s. str. Two of these, $P$. manni Brues and P. dominicæ Pollard, var. haitiensis Brues had been previously described by the writer from material collected by Dr. Wm. M. Mann. ${ }^{1}$

The other three are additional forms of $P$. dominicx and were described as varieties by the writer from Dr. Darlington's material. ${ }^{2}$

Quite recently Dr. Austin H. Clark ${ }^{3}$ described another species belonging to the related genus Macroperipatus from Haiti as M. insularis. This augments the list of Haitian Onychophora to six, including two genera and three species, one of the latter with four named varieties.

Last autumn Dr. Darlington again visited Haiti, this time extending his investigations eastward into the north and central portions of the Dominican Republic. There he secured series of Peripatus at five additional localities.

An examination of these series shows them all to be referable to $P$. dominicx Pollard, var. basilensis Brues previously known from Mount Basil in the northwestern part of the island.

The distribution of basilensis is thus greatly extended by this material as indicated below.

(1) Mt. Diego de Ocampo, Northern Range, Dominican Republic. 3500-4000 feet (July 1938). One specimen, quite typical, but with 30 pairs of legs instead of 28 as in the type.

(2) North slope of Loma Rucilla, Central Range, Domin-

${ }^{1}$ Bull. Mus. Comp. Zool., vol. 54, pp. 519-521 (1913).

2Psyche, vol. 42, pp. 58-62 (1935).

3Proc. U. S. National Mus., vol. 85, No. 3027, p. 3 (1937). 
ican Republic, about 8000 feet (June 1928). Six specimens with 27 pairs (four individuals) or 28 pairs of legs (two individuals).

(3) North of Loma Rucilla, Central Range, Dominican Republic, 6000-7000 feet (June 1938). Two large females, each with only 26 pairs of legs.

(4) Constanza, Central Range, Dominican Republic, 3000-4000 feet (August 1938). Eight specimens with 27-31 pairs of legs; one $\hat{o}$ with 27 pairs, one with 29 pairs, four with 30 pairs and two with 31 pairs.

(5) Vic Valle Neuvo, southeast of Constanza, Central Range, about 7000 feet (August 1938). Two specimens, each with 28 pairs of legs.

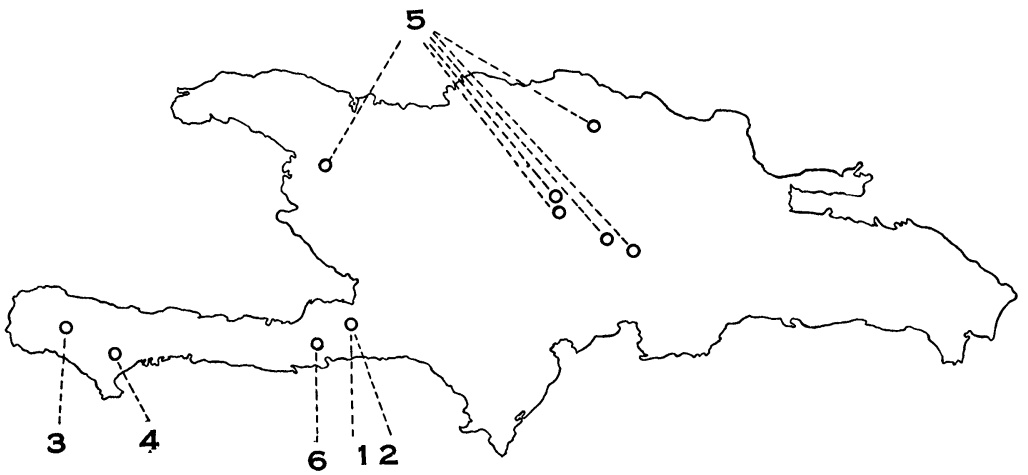

Fig. 1. Outline map of Haiti showing the known distribution of Onychophora. 1, Peripatus manni; 2, Peripatus dominica, var. haitiensis; 3, Peripatus dominicx, var. darlingtoni; 4, Peripatus dominicæ, var. lachauxensis; 5, Peripatus dominicæ, var. basilensis; 6, Macroperipatus insularis.

It thus appears that Peripatus dominicæ var. basilensis extends eastward from Mt. Basil into the Northern Range of Mountains and also into the Central Range. All of the specimens listed above are very similar to the types although many of them have more pairs of legs. However, the number apparently never reaches that present in what I have considered to be the nearest relative, var. darlingtoni Brues which is so far known only from well out on the southwestern peninsula on the Massif de la Hotte.

The accompanying outline map, kindly drawn for me by Mrs. A. S. O'Connor summarizes our present knowledge of the distribution of Onychophora on the island of Haiti. 

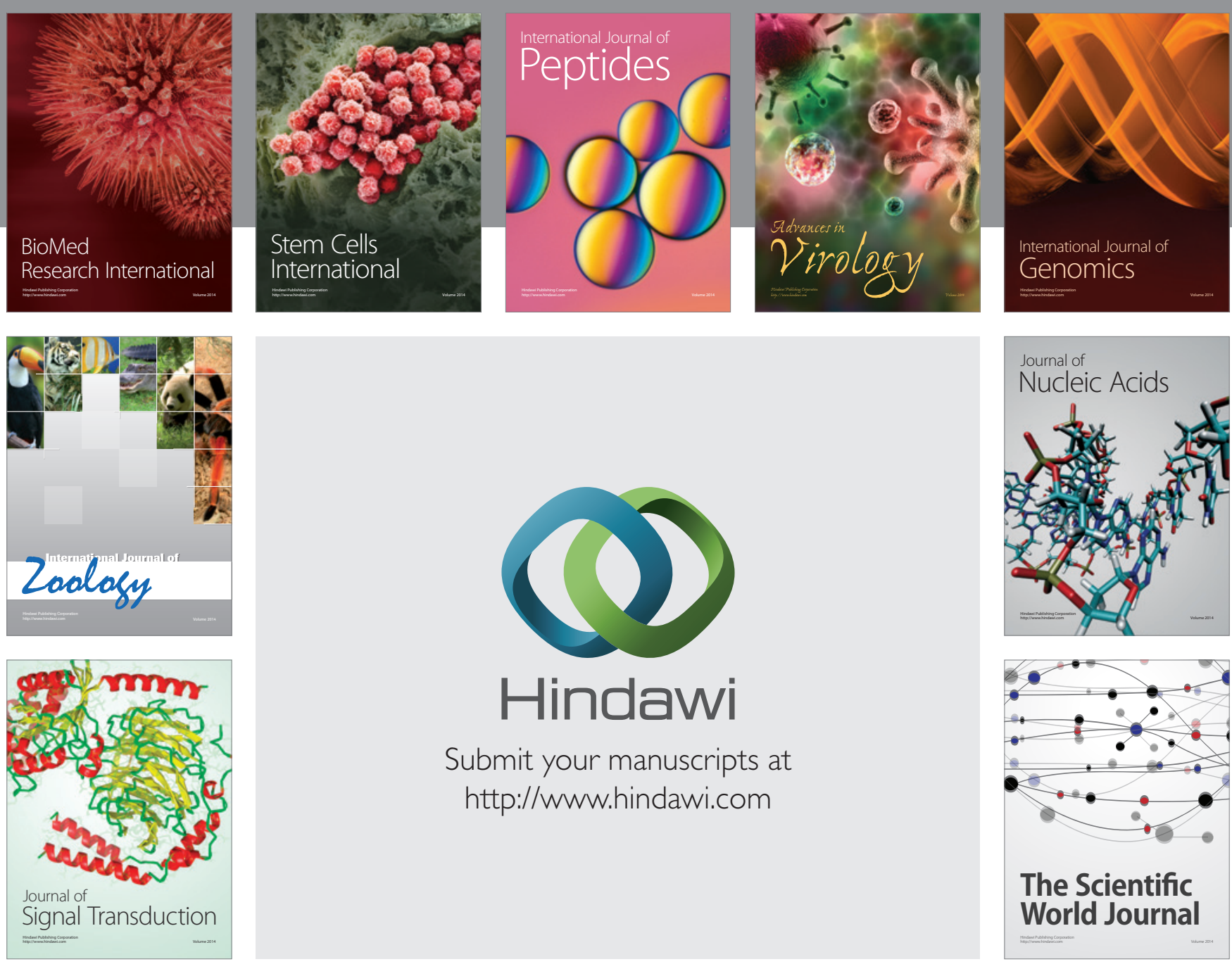

Submit your manuscripts at

http://www.hindawi.com
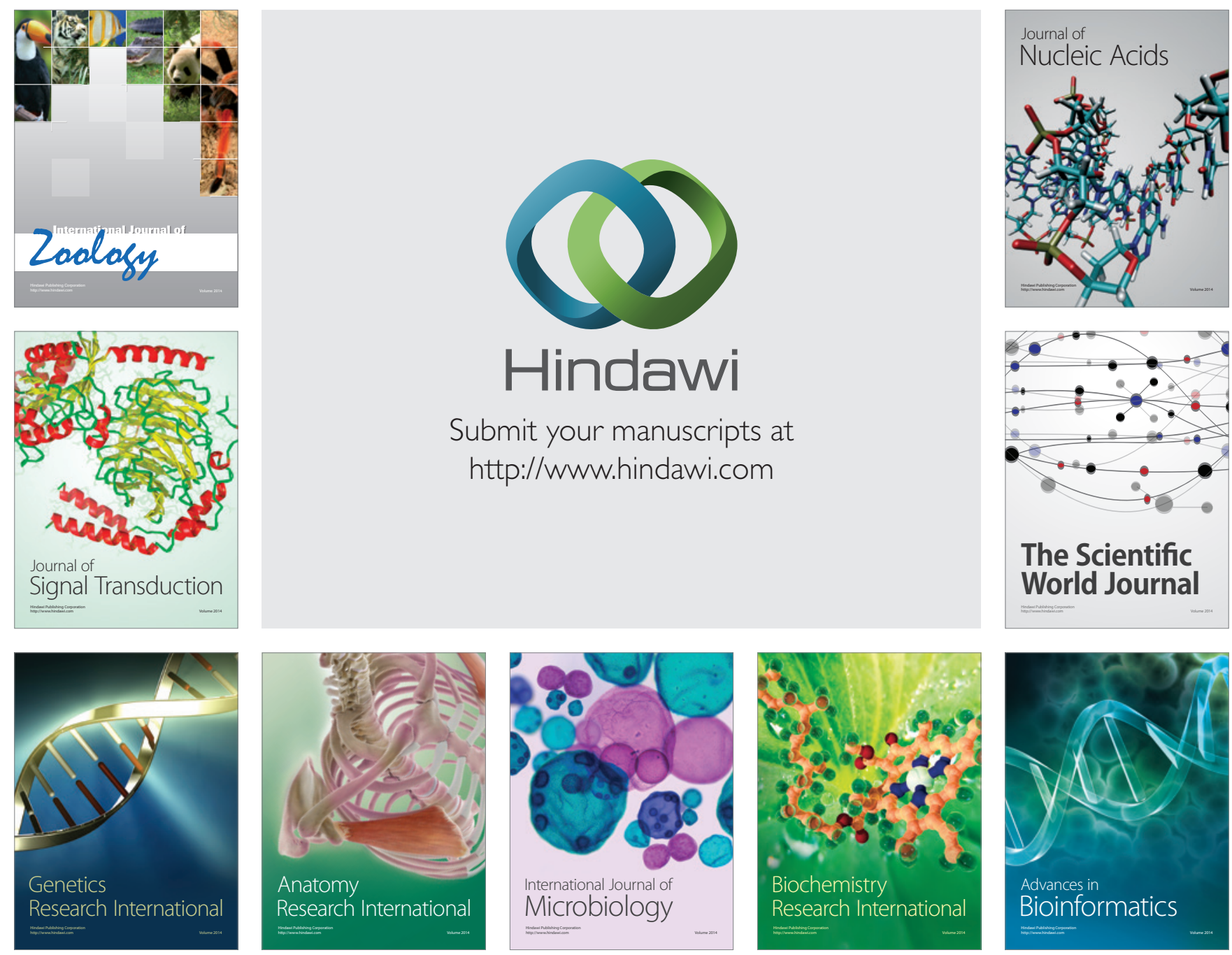

The Scientific World Journal
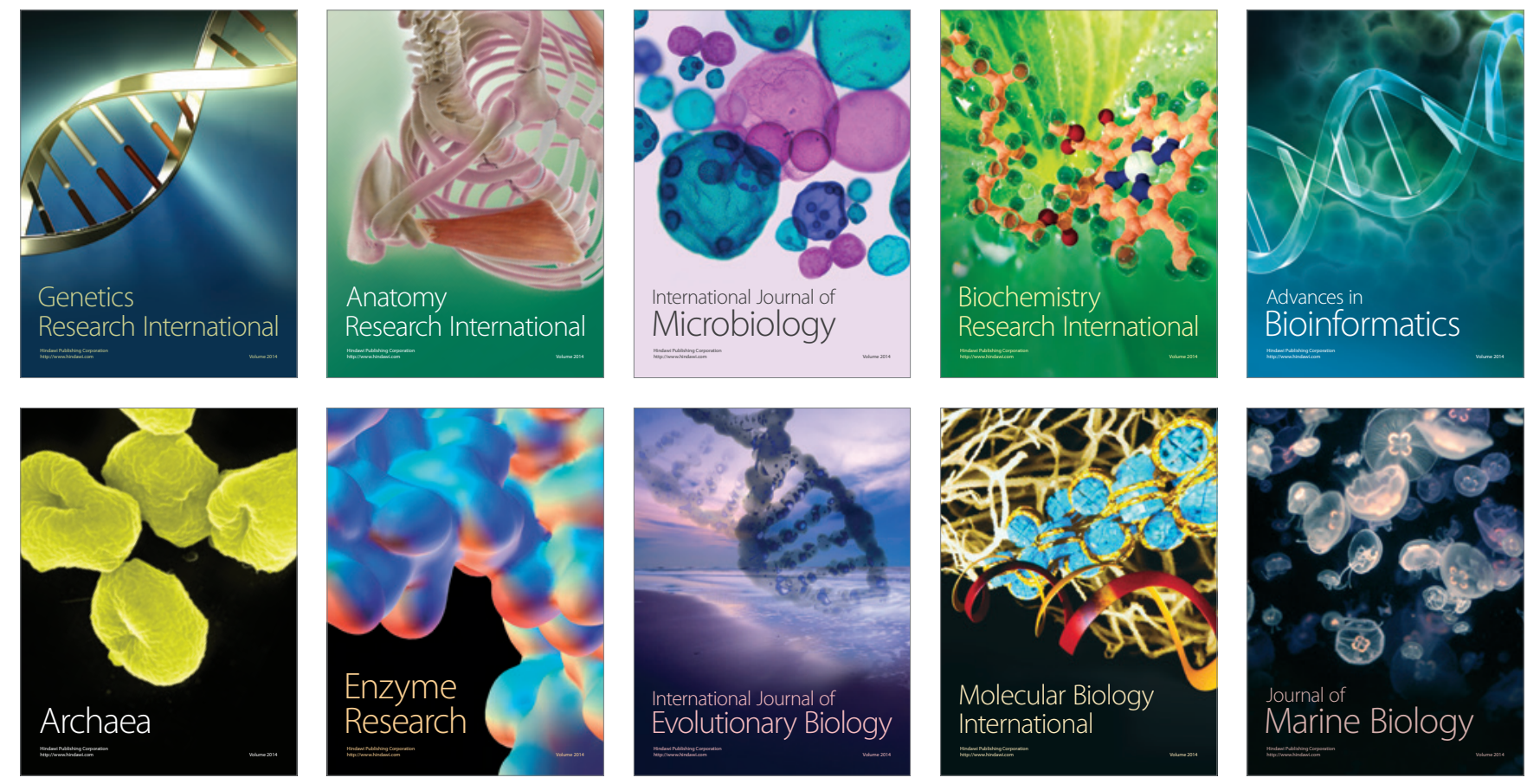